\title{
A Cross-Cultural Comparison of E-Banks Based on Multiple Mediations of Trust
}

\author{
Thi Mai Le \\ National Pingtung University of Science and Technology \\ E-Mail: lemai.istnu@gmail.com \\ Nur Aisyah Dwi Hediasri \\ National Pingtung University of Science and Technology \\ E-Mail: aisyahhediasri@gmail.com \\ Shu-Yi Liaw* \\ National Pingtung University of Science and Technology \\ E-Mail: syliaw@mail.npust.edu.tw
}

\begin{abstract}
This study tests the importance of the dimensions of trust. Benevolence, ability and integrity mediate the relationship between customer satisfaction and loyalty. This study compared users' behavior between Indonesia and Taiwan with data from 300 internet banking users from the four biggest banks of each country. Six hundred samples were analyzed using SPSS and SmartPLS 2.0 software for Partial Least Square (PLS) analysis. The major findings are as follows. Customer satisfaction has a positive direct effect on customer loyalty. Benevolence is the most important element of trust. In Indonesia, benevolence and ability mediate the relationship between customer satisfaction and customer loyalty. Integrity does not, because users of internet banking are aware of honesty and fulfillment of promises. In Taiwan, benevolence and integrity have mediate the relationship between customer satisfaction and customer loyalty but ability does not. The findings of this survey provide researchers and managers with valuable information on the importance of trust in the relationship between customer satisfaction and customer loyalty.
\end{abstract}

Keywords: Customer Satisfaction, Trust, Benevolence, Ability, Integrity, Customer Loyalty

\footnotetext{
${ }^{*}$ Corresponding author
} 


\section{INTRODUCTION}

Internet banking has become a main way for banks to deliver their products and services (Wong, Loh, Yap, \& Bak, 2009). The fastest-growing financial services on banks' websites are transactions, where the customer cab access basic (such as account balances, fund transfers, and bill payment) and advanced services (such as access to credit and the ability to make investments). Consumers often face temporal separation when transactions are carried out online and do not involve a simultaneous transaction of services and money (Grabner-Kräuter \& Faullant, 2008). As a result, consumers can become uncertain whether the other parties will carry out their side of the transaction. Another reason for the increased need for trust in the online banking is consumers' fear for the safety and confidentiality of their personal information (Yoon, 2002).

Trust exists where there is risk, uncertainty and interdependence (Wong et al., 2009), and the online environment certainly has these characteristics. In an online environment, there is no direct physical contact between buyer and seller. Trust is important in online environments because the consumer has few tangible and verifiable cues regarding the service provider's capabilities and intentions (Urban, Sultan, \& Qualls, 2000). In online banking, although the trading interface may appear fast and convenient, the background processes, such as order flow, price discovery, and order execution, remain inscrutable (Konana, Menon, \& Balasubramanian, 2000). Slenders (2011) found three prerequisites of trust: benevolence (trustee caring and motivation to act in the truster's interests), ability (competence of the trustee to do what the truster needs), and integrity (trustee honesty and promise keeping). Trust in an internet vendor leads customers to focus on that vendor's service (Chen \& Dhillon, 2003).

Some marketing researchers see trust as a major antecedent of customer loyalty (Harris \& Goode, 2004). Trust can reduce the risk in the relationship between a company and its customers. Kassim and Abdullah (2010) found that customer loyalty was affected by satisfaction and trust. Satisfied customers will trust a company and be loyal to it. Customer loyalty can reduce marketing costs and enable the company to survive intense competition. In these ways, trust can be a mediator between customer satisfaction and customer loyalty.

Many researchers have used different sub-dimensions for each construct in their research, so different studies reached different conclusions. There has been limited comparative research in customer satisfaction, trust and customer loyalty, the internet banking. This research, therefore, was reveals the effect of customer satisfaction on customer loyalty. Based on the mapping result of prior research, there has been a 
systematic effort to refine the relationship between satisfaction and loyalty; the mediating variable of customer satisfaction and customer loyalty is still unknown. Some previous studies have mentioned trust, which mediate this relationship, but the dimensions of trust have been neglected in many studies in developing countries. This study therefore emphasizes the importance of trust as a mediator between customer satisfaction and customer loyalty.

This research explores the mediating effect of benevolence, ability, and integrity on the relationship between customer satisfaction and customer loyalty by comparing Taiwan and Indonesia. The study uses a multi-mediation model, in order to determine which dimension of trust has the strongest mediating effect. The research adds to the marketing literature on customer satisfaction, trust, and customer loyalty.

\section{LITERATURE REVIEW}

\section{Customer loyalty}

According to Kocoglu (2012), loyalty is the long and uninterrupted retention of a relationship by offering service that meets and even exceeds customer needs. Each company therefore strives to provide better products and services than those of its competitors. In this way, the company can survive, succeed, and focus on its customers. The foundation for a company's survival is its loyal customers, and it should be the goal of all companies. Loyal customers will generate higher profits for the company through repeat purchases.

In business, loyalty describes the willingness of customers to continue subscribing to, purchasing, and recommending products and services to friends or colleagues. Building customer loyalty is difficult, because customers are picky about products and services. Customer loyalty maintains a company's financial status and viability. Kotler and Keller (2012) defined loyalty as a deeply held commitment to rebuying preferred products or services despite situational influences and marketing efforts that could cause switching behavior.

Customers will declare themselves loyal to a supplier through feelings and perceptions of satisfaction, positive attitudes and preferences. These customers will be willing to repurchase from this supplier, according to Hollensen (2010). Customer satisfaction and customer belief can build customer loyalty to an e-service provider (Sobihah et al., 2015). Loyal customers will interact more with the company, as their satisfaction and comfort increase. Customer loyalty can be achieved by providing the best service and ensuring customers' complete satisfaction. Customers who are loyal 
to a bank will contribute to its survival (van Esterik-Plasmeijer, van Esterik-Plasmeijer, van Raaij, \& van Raaij, 2017).

\section{The Relationship between Customer Satisfaction and Loyalty}

The customer is an important component of a business, so that first step to creating customer loyalty is customer satisfaction. Satisfaction is the motivation for the ongoing purchase of goods and services (Kim et al., 2008). Customer satisfaction is a variable that connect the moderator variables and customer loyalty (Liao \& $\mathrm{Wu}$, 2009). Customer satisfaction makes customer retention possible. Whether the buyer is satisfied depends on the product's performance in relation to the buyer's expectations. Kotler and Keller (2012) defined satisfaction as a person's happiness or disappointment with a product's perceived performance in relation to his or her expectations. If the performance falls short of expectations, the customer is dissatisfied. If the performance matches the expectations, the customer is satisfied. However, if the performance exceeds expectations, the customer is delighted.

Kim et al. (2008) defined satisfaction as involving at least two stimuli, an outcome and a comparison referent. Customer satisfaction is a complex determinant factor with both cognitive and affective components. Liao and $\mathrm{Wu}$ (2009) stated that satisfaction can also reflect the emotional evaluation of the extent to which customers associated the ownership and use of the product or service with positive feelings about a company.

Many companies aspire to delight their customers. Customers who are highly satisfied will be more loyal and less ready to switch (Kotler, 2000). Retaining customers and strengthening loyal customer is important for a company's competitive advantage (Deng et al., 2010). Liao and Wu (2009) cited customer satisfaction as a key to increased customer loyalty. Therefore, many companies focus on customer satisfaction as a means to customer loyalty. Liao and $\mathrm{Wu}$ (2009 stated that customer satisfaction can affect retention intentions and customer buying behavior, both of which eventually have an impact on customer loyalty. In their study, Kassim and Abdullah (2010) reported that customer satisfaction is an antecedent of and positively related to customer loyalty. In services, several researchers have explored the relationship between satisfaction and loyalty (Akbar \& Parvez, 2009; Bricci, Fragata, \& Antunes, 2016; Chen et al., 2013; Prougestaporn, Visansakon, \& Saowapakpongchai, 2015). Customer satisfaction is one of the main antecedents of customer loyalty (Setó-Pamies, 2012). This leads to the first hypothesis of the model. Hypothesis $\left(\mathrm{H}_{1}\right)$ : Customer satisfaction has a positive direct effect on customer loyalty. 


\section{The Mediating Role of Dimensions of Trust}

Kim et al. (2008) defined trust as a set of specific relationship intentions dealing primarily with integrity, benevolence, competence, and predictability. It illustrated the role of trust as being vital to a successful customer relationship. Dwyer and Tanner (2002) described trust as the belief that a party's word or promise is reliable and a party will live up to his or her obligations in an exchange relationship. The trusting party derives confidence from a belief that other party is consistent, honest, fair, responsible, and helpful. Usman (2015) stated that trust is an important element in customer relationship management (CRM) and e-banking adoption. Other studies who have mentioned trust and its dimensions are van Esterik-Plasmeijer, van EsterikPlasmeijer, van Raaij, and van Raaij (2017), Hollensen (2010), Kotler and Keller (2012), and Chu et al. (2012). Slenders (2011) found that there are three elements of trust: benevolence, integrity, and ability. If one is missing, trust does not exist.

\section{- Benevolence}

Slenders (2011) described benevolence as "the extent to which a trustee is believed to want to do good to the trustor, aside from an egocentric profit motive." Benevolence acts with caring about the other person, not having interest, and not benefiting from the relationship. The trustee is genuinely interested in the trustor's welfare and motivated to seek joint gain, the trustee has motived beneficial to the trustor when new conditions arise for which a commitment was not made.

\section{- Ability}

Ability consists of the knowledge, skills, or competencies that allow an individual to have influence in an area (Slenders, 2011). It means that the trustee must be knowledgeable or skillful in the area that is important to the trustor. This premise was supported by Komiak and Benbasat (2004), who defined ability as the belief that a trustee has the ability or power to do for a trustor what the trustor needs to be done; trust in trustee's technical capabilities, skills; trust in technically competent and dependable performance; the belief that a trustee is capable of living up to the contract; or trust in the skills, competencies and perceived expertise that enable a trustee to perform effectively in a domain.

\section{- Integrity}

Integrity is the trustor's perception that the trustee adheres to a set of principles that the trustor finds acceptable (Slenders, 2011). This means that each partner in the relationship must agree on the same principles. Komiak and Benbasat (2004) defined 
integrity as the belief that a trustee makes good faith agreements, tells the truth, and keeps promises; or the trustor's perception that the trustee will respect the initial agreement.

Madjid et al. (2013) found that customer' trust mediates the influence of customer satisfaction on customer loyalty. These findings were supported by Horppu et al. (2008), who found a positive linkage between website satisfaction, website trust, and website loyalty in the online brand relationship. Kim et al. (2008) speculated that a customer's satisfaction with an online retailer leads to trust and commitment (loyalty). Capgemini (2012) mentioned that despite their high satisfaction, $40 \%$ of customers are not sure whether they will stay with the primary bank. Chu et al. (2012), Kassim and Abdullah (2010), and Al-dweeri et al. (2017) mentioned that trust and customer satisfaction have a positive impact on e-loyalty. They also provided insight into the role of trust in internet banking. When online users confront the unfamiliar, uncertain, and unsafe virtual transaction environment, e-banking providers must earn the trust of those users. Chen and Dhillon (2003) determined customers' trust in an internet vendor in terms of competence (ability), integrity, and benevolence. This claim was supported by Slenders (2011), who stated that ability, integrity, and benevolence must be in place for trust to exist. Therefore,

Hypothesis $\left(\mathrm{H}_{2}\right)$ : Benevolence is a mediator of the relationship between customer satisfaction and customer loyalty

Hypothesis $\left(\mathrm{H}_{3}\right)$ : Ability is a mediator of the relationship between customer satisfaction and customer loyalty

Hypothesis $\left(\mathrm{H}_{4}\right)$ : Integrity is a mediator of the relationship between customer satisfaction and customer loyalty

\section{METHODOLOGY}

This study examines the multiple mediations of trust in the relationship between customer satisfaction and customer loyalty among users of internet banking. The research model is shown in figure 1. The study is based on the research by Deng et al. (2010); Liao and Wu (2009); Yang et al. (2009); Kuo, Wu, and Deng (2009); Chu et al. (2012); Sheng and Liu (2010); Kassim and Abdullah (2010); Ladhari and Leclerc (2013); and Chen (2012). Therefore, this study tests the importance of the three dimensions of trust -- benevolence, ability, and integrity - in mediating the relationship between customer satisfaction and customer loyalty. 


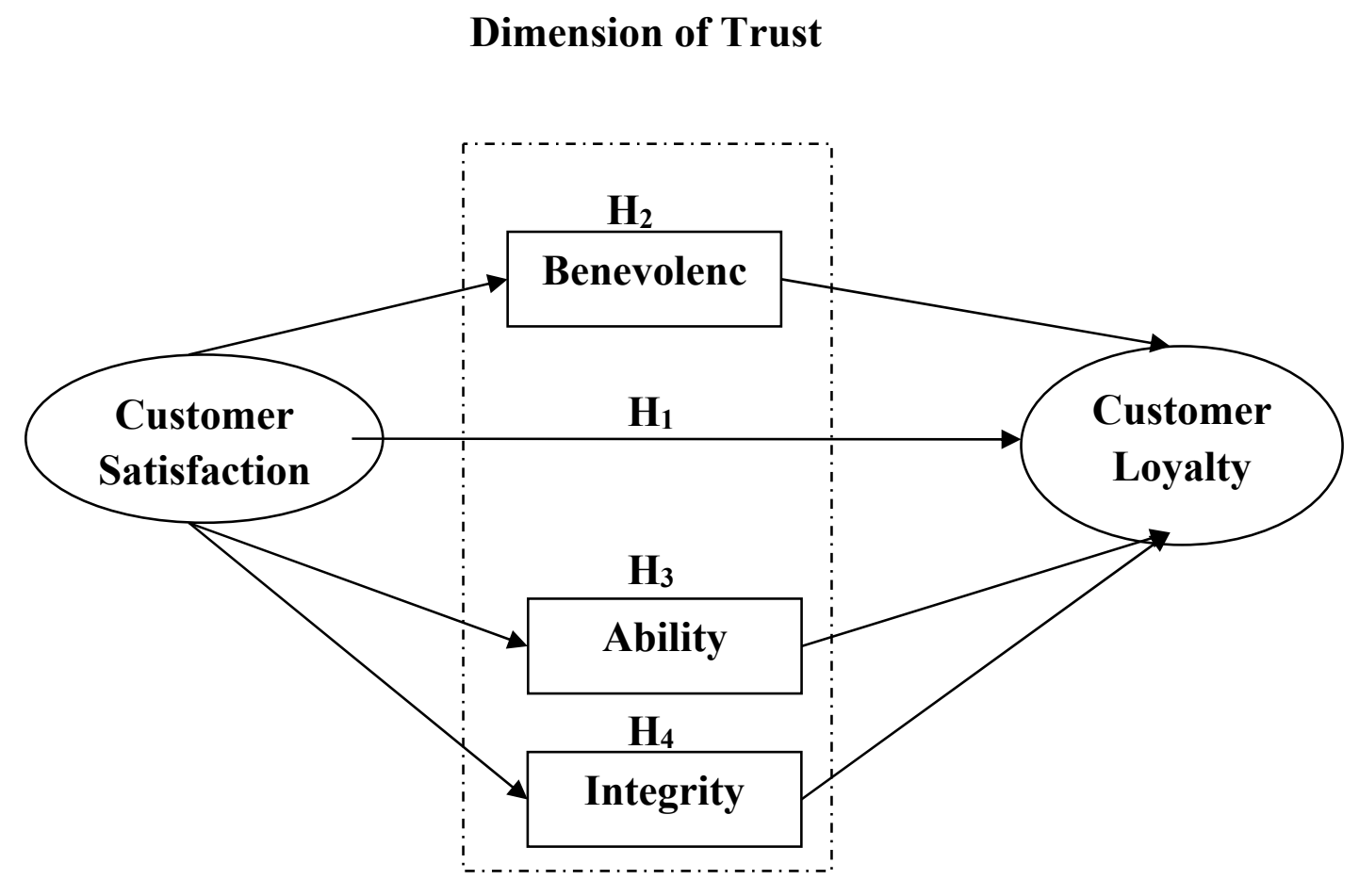

Figure 1 Research Model

The questionnaire was adapted from previous studies and validated with a pilot test. All responses were made using a five-point Likert scale $(1=$ Strongly disagree to $5=$ Strongly agree). The variable constructs, items are as shown in table 1.

This study was conducted in Indonesia and Taiwan because they are developing countries in Asia; there are much cultural differences between Taiwan and Indonesia. ; they have many large banks that provide e-banking services; and because their citizens are well-versed in banking and other financial activities. The target population were the four biggest banks that provides internet banking facilities in both countries: Bank Mandiri, Bank Negara Indonesia, Bank Central Asia, and Bank Rakyat Indonesia in Indonesia and Taiwan Cooperative Bank, Taishin Financial Holding, First Financial Holding, and Chinatrust Financial Holding in Taiwan.

To determine the sample size, the study followed Kline's (2005) recommendations. A desirable goal was to have a 20:1 or a 10:1 ratio of cases to free parameters. Based on this research path model, this study had a minimum sample size of 300 cases for each country or a total population of 600 internet banking users. 
Table 1 Variable Constructs Definition

\begin{tabular}{|c|c|c|}
\hline Construct & Items & Sources \\
\hline Satisfaction & $\begin{array}{l}\text { Feeling wise to choose the internet banking } \\
\text { Internet banking capability of providing the total } \\
\text { solution } \\
\text { E-service always conforms to the requirement of } \\
\text { customer } \\
\text { Customer satisfied with the e-service internet } \\
\text { banking provide }\end{array}$ & $\begin{array}{l}\text { Kassim and Abdullah } \\
\text { (2010); Chu et al. (2012); } \\
\text { Kim et al. (2008); Sheng } \\
\text { and Liu (2010); Liao and } \\
\text { Wu (2009); Deng et al. } \\
\text { (2010) }\end{array}$ \\
\hline Benevolence & $\begin{array}{l}\text { Believe e-banking site would act in best interest. } \\
\text { Believe this e-banking site would do its best to help. } \\
\text { E-banking site is interested in customer well-being. }\end{array}$ & \multirow{3}{*}{$\begin{array}{l}\text { Kassim and Abdullah } \\
\text { (2010); Liao and Wu } \\
\text { (2009); Kim et al. } \\
\text { (2008);McKnight, } \\
\text { Choudhury, and Kacmar } \\
\text { (2002); Chu et al. (2012); } \\
\text { Komiak and Benbasat } \\
\text { (2004) }\end{array}$} \\
\hline Ability & $\begin{array}{l}\text { The competency and effectiveness of e-banking site } \\
\text { in providing banking service } \\
\text { The banking site performs the role of giving banking } \\
\text { service very well. } \\
\text { The capability and the proficiently of e-banking site } \\
\text { as internet banking service provider }\end{array}$ & \\
\hline Integrity & $\begin{array}{l}\text { Trust to dealing with e-banking site } \\
\text { Characterize the e-banking site as honest. } \\
\text { Sincerity and genuinely of e-banking site }\end{array}$ & \\
\hline Loyalty & $\begin{array}{l}\text { Intend to continue doing business with this e-banking } \\
\text { Customer don't think of changing this e-banking } \\
\text { easily } \\
\text { Recommend the e-banking service to other people } \\
\text { Recommend this e-banking site to others }\end{array}$ & $\begin{array}{l}\text { Kassim and Abdullah } \\
\text { (2010); Roostika (2011); } \\
\text { Chu et al. (2012); Liao and } \\
\text { Wu (2009); Yang et al. } \\
\text { (2009); }\end{array}$ \\
\hline
\end{tabular}

The respondents' demographics consisted of bank, usage duration, and usage frequency, types of service, gender, age, occupation, and education. In Indonesia, nearly $30 \%$ of all respondents used Bank Mandiri, Bank Negara Indonesia and Bank Central Asia, and 13\% used Bank Rakyat Indonesia. In Taiwan, 39.8\% of respondents used First Financial Holding, 22.7\% used Taiwan Cooperative Bank, 18.8\% use Chinatrust Financial Holding and 18.8\% used Taishin Financial Holding. The most customers' usage duration was from 3 months to 3 years in Taiwan and Indonesia (72.7\% and 55.5\%). The largest respondents in Indonesia have 1-3 times per week (43.2\%) to use e-bank service, but less than once per week in Taiwan (59.4\%). The majority of the respondents used e-service types which included: check the balance, money transfer, e-payment and e-purchase in both countries. For Indonesian respondents, $31.8 \%$ respondents are $17-23$ years old, $40.9 \%$ are $24-30$ years old, $18.9 \%$ are $31-37$ years old, and $8.3 \%$ are $38-44$ years old. Among the Taiwanese 
respondents, $32 \%$ respondents are $17-23$ years old, $37.5 \%$ are $24-30$ years old, $11.7 \%$ are $31-37$ years old, $8.6 \%$ of are $38-44$ years old, and $10.2 \%$ respondents are $45-51$ years old. In Indonesia, $24.2 \%$ of respondents have a high school diploma, $53.8 \%$ have a bachelor's degree, and 22\% have a master's degree. In Taiwan, 39.8\% of respondents have a bachelor's degree and $60.2 \%$ have a master's degree.(table 2). Because gender, age, occupation and education did not have a significant effect, they are not further considered.

Table 2 Summary Sample Characteristics of Internet Banking User $(n=300$ for each country)

\begin{tabular}{|c|c|c|c|c|c|}
\hline \multirow{2}{*}{$\begin{array}{c}\text { Demographic } \\
\text { Variable }\end{array}$} & \multirow[b]{2}{*}{ Characteristic } & \multicolumn{2}{|c|}{ Indonesia } & \multicolumn{2}{|c|}{ Taiwan } \\
\hline & & Frequency & $\begin{array}{c}\text { Percentage } \\
(\%)\end{array}$ & Frequency & $\begin{array}{c}\text { Percentage } \\
(\%)\end{array}$ \\
\hline \multirow{6}{*}{ Age } & 17-23 years old & 95 & 31.8 & 96 & 32.0 \\
\hline & 24-30 years old & 123 & 40.9 & 112 & 37.5 \\
\hline & 31-37 years old & 57 & 18.9 & 35 & 11.7 \\
\hline & 38-44 years old & 25 & 8.3 & 26 & 8.6 \\
\hline & 45-51 years old & - & - & 31 & 10.2 \\
\hline & $\geq 52$ years old & - & - & - & - \\
\hline \multirow{4}{*}{ Education } & Junior High School & - & - & - & - \\
\hline & Senior High School & 73 & 24.2 & & - \\
\hline & Bachelor's degree & 161 & 53.8 & 119 & 39.8 \\
\hline & Master's degree & 66 & 22.0 & 181 & 60.2 \\
\hline
\end{tabular}

\section{RESULTS AND DISCUSSION}

A two-stage procedure was used to analyze the data. Confirmatory factor analytics was conducted to assess the measurement model and then the structural model was examined. We used SPSS and Smart PLS 2.0 for the data analysis. Reliability analysis was tested by Cronbach's $\alpha$ coefficient (table 3 ). The Cronbach's $\alpha$ ranged from 0.650 to 0.853 . All factors with a reliability coefficient above 0.6 with a recommended value 0.5 (Hair et al., 2010) were considered acceptable in this study. 
Table 3 Reliabilities among The Variables

\begin{tabular}{lccccccc}
\hline \multirow{2}{*}{ Variable } & \multirow{2}{*}{ Items } & \multicolumn{3}{c}{ Indonesia } & \multicolumn{4}{c}{ Taiwan } \\
\cline { 2 - 8 } & & $\mathrm{M}$ & Std & Cronbach's $\alpha$ & $\mathrm{M}$ & Std & Cronbach's $\alpha$ \\
\hline $\begin{array}{l}\text { Customer } \\
\text { Satisfaction }\end{array}$ & 4 & 3.907 & 0.533 & 0.771 & 3.854 & 0.454 & 0.774 \\
Benevolence & 3 & 3.694 & 0.524 & 0.730 & 3.742 & 0.539 & 0.688 \\
Ability & 3 & 4.005 & 0.447 & 0.650 & 3.888 & 0.445 & 0.666 \\
Integrity & 3 & 3.631 & 0.489 & 0.734 & 3.766 & 0.586 & 0.853 \\
Customer Loyalty & 2 & 3.833 & 0.537 & 0.794 & 3.717 & 0.564 & 0.757 \\
\hline
\end{tabular}

\section{Measurement Model}

The evaluation of the reflective measurement models examines their reliability and validity (Henseler et al., 2009). According to Hair et al. (2014), the outer loadings should be higher than 0.40 . Indicators whose outer loadings are less than 0.40 should be eliminated from the models. The average variance extracted (AVE) should have a value of 0.50 or higher. Table 4 shows the composite reliability and average variance extracted in the final measurement. The outer loadings were checked: the lowest value was 0.584 , higher than the recommended value of 0.4 . Convergent validity was assessed by examining AVE from the measures; it ranged from 0.587 to 0.773 , well above the recommended value of 0.5 , thus showing convergent validity. According to table 5, this model already passed the requirement of discriminant validity. For the Fornell-Larcker criterion, the square root of AVE of each construct in Indonesian model and Taiwan model is higher than its highest correlation with any other construct (Henseler et al., 2009). It means both the Indonesian and the Taiwanese models have discriminant validity.

The evaluation of formative measurement models, at the indicator level, tests for potential multicollinearity between items and analyzes weights (Henseler et al., 2009). A collinearity test was performed by SPSS. Resulting VIF values achieved good condition for all constructs in the model. According to the results, for Indonesia Model, L3 has the lowest tolerance (0.262) and the highest VIF value (3.822), and for Taiwan Model, L3 has the lowest tolerance (0.400) and the highest VIF value (2.500). Hence, the tolerance levels and VIF values are uniformly higher and below the threshold value of 0.2 and 5. Therefore, collinearity does not reach critical levels in any construct and is not an issue for the further estimation of the PLS model. 
Table 4 Convergent Validity of Multiple Mediation Model

\begin{tabular}{|c|c|c|c|c|c|}
\hline \multirow[b]{2}{*}{ Variable } & \multirow[b]{2}{*}{ Path } & \multicolumn{2}{|c|}{ Indonesia } & \multicolumn{2}{|c|}{ Taiwan } \\
\hline & & $\begin{array}{l}\text { Outer } \\
\text { Loadings }\end{array}$ & $\begin{array}{c}\text { Average } \\
\text { Variance } \\
\text { Extracted } \\
\text { (AVE) }\end{array}$ & $\begin{array}{l}\text { Outer } \\
\text { Loadings }\end{array}$ & $\begin{array}{c}\text { Average } \\
\text { Variance } \\
\text { Extracted } \\
(\mathrm{AVE})\end{array}$ \\
\hline \multirow{4}{*}{$\begin{array}{c}\text { Customer } \\
\text { Satisfaction (CS) }\end{array}$} & $\mathrm{CS} 1<-\mathrm{CS}$ & 0.673 & \multirow{4}{*}{0.591} & 0.698 & \multirow{4}{*}{0.598} \\
\hline & $\mathrm{CS} 2<-\mathrm{CS}$ & 0.847 & & 0.775 & \\
\hline & $\mathrm{CS} 3<-\mathrm{CS}$ & 0.793 & & 0.819 & \\
\hline & CS4 <- CS & 0.751 & & 0.797 & \\
\hline \multirow{4}{*}{$\begin{array}{c}\text { Customer } \\
\text { Loyalty (CL) }\end{array}$} & $\mathrm{L} 1<-\mathrm{CL}$ & 0.789 & \multirow{4}{*}{0.622} & 0.658 & \multirow{4}{*}{0.585} \\
\hline & $\mathrm{L} 2<-\mathrm{CL}$ & 0.692 & & 0.691 & \\
\hline & $\mathrm{L} 3<-\mathrm{CL}$ & 0.842 & & 0.858 & \\
\hline & $\mathrm{L} 4<-\mathrm{CL}$ & 0.823 & & 0.833 & \\
\hline \multirow{3}{*}{$\begin{array}{l}\text { Benevolence } \\
\text { (T1) }\end{array}$} & $\mathrm{T} 1 \_1<-\mathrm{T} 1$ & 0.831 & \multirow{3}{*}{0.646} & 0.615 & \multirow{3}{*}{0.618} \\
\hline & $\mathrm{T} 1 \_2<-\mathrm{T} 1$ & 0.819 & & 0.876 & \\
\hline & $\mathrm{T} 1 \_3<-\mathrm{T} 1$ & 0.760 & & 0.841 & \\
\hline \multirow{3}{*}{ Ability (T2) } & $\mathrm{T} 2 \_4<-\mathrm{T} 2$ & 0.584 & \multirow{3}{*}{0.587} & 0.651 & \multirow{3}{*}{0.600} \\
\hline & $\mathrm{T} 2 \_5<-\mathrm{T} 2$ & 0.860 & & 0.789 & \\
\hline & $\mathrm{T} 2 \_6<-\mathrm{T} 2$ & 0.826 & & 0.869 & \\
\hline \multirow{3}{*}{ Integrity (T3) } & $\mathrm{T} 3 \_7<-\mathrm{T} 3$ & 0.803 & \multirow{3}{*}{0.650} & 0.832 & \multirow{3}{*}{0.773} \\
\hline & T3_8<- T3 & 0.754 & & 0.894 & \\
\hline & T3_9<- T3 & 0.858 & & 0.910 & \\
\hline
\end{tabular}

Table 5 Matrix of Discriminant Validity in Multiple Mediation Model

\begin{tabular}{|c|c|c|c|c|c|c|c|c|c|c|c|}
\hline \multicolumn{6}{|c|}{ Indonesia } & \multicolumn{6}{|c|}{ Taiwan } \\
\hline & CL & $\mathrm{CS}$ & $\mathbf{T 1}$ & $\mathbf{T} 2$ & $\mathbf{T 3}$ & & CL & $\mathrm{CS}$ & $\mathbf{T 1}$ & $\mathbf{T} 2$ & $\mathbf{T 3}$ \\
\hline CL & 0.789 & & & & & CL & 0.765 & & & & \\
\hline CS & 0.617 & 0.769 & & & & CS & 0.426 & 0.774 & & & \\
\hline T1 & 0.522 & 0.449 & 0.804 & & & $\mathbf{T 1}$ & 0.512 & 0.494 & 0.786 & & \\
\hline $\mathbf{T} 2$ & 0.504 & 0.574 & 0.466 & 0.766 & & $\mathbf{T} 2$ & 0.349 & 0.611 & 0.579 & 0.775 & \\
\hline T3 & 0.399 & 0.360 & 0.598 & 0.399 & 0.806 & T3 & 0.475 & 0.484 & 0.600 & 0.456 & 0.879 \\
\hline
\end{tabular}




\section{Structural Model}

\section{- The Impact of Customer Satisfaction on Customer Loyalty}

Based on the results in Table 6, the direct effect of customer satisfaction (CS) is significant in Indonesia $(\beta=0.414, p=0.000)$ and Taiwan $(\beta=0.198, p=0.000)$. So, hypothesis $H_{1}$ is supported in Indonesia and Taiwan. It means customer satisfaction has a positive direct effect on customer loyalty. These results are consistent with studies by Kasiri et al. (2017); Picón (2014), Ladhari and Leclerc (2013); Kuo et al. (2009); Sheng and Liu (2010); Akbar and Parvez (2009) and Chu et al. (2012). They found that customer satisfaction had a positive and significant influence on customer loyalty. Customer satisfaction was found to be important in increasing customer loyalty. These findings imply that internet banking providers should strive to improve customer satisfaction in order to build customer loyalty.

- The Mediation Effect Test of Benevolence, Ability and Integrity Tests on the mediation hypotheses $\left(\mathrm{H}_{2}, \mathrm{H}_{3}\right.$ and $\left.\mathrm{H}_{4}\right)$ used an application of the analytical approach that Preacher and Hayes (2008) described. In Table 6, we obtained $\beta$ coefficient, z-value, standard error (SE) and $p$-value by Sobel test.

In Indonesia, benevolence and ability were found to be significant mediators in the relationship between satisfaction and loyalty $(\beta=0.109 ; z=3.682 ; p=0.000)$ and $(\beta=0.076 ; z=2.637 ; p=0.008)$. These results supported hypotheses $\mathrm{H}_{2}$ and $\mathrm{H}_{3}$ in the Indonesian model. These findings are consistent with those of Flavián et al. (2006) and Singh and Sirdeshmukh (2000), who supported that benevolence and ability mediates the effect of customer satisfaction on customer loyalty. However, integrity was not found to have statistical significant mediating effects $(\beta=0.019 ; z=1.116, p=$ 0.264). This means that hypothesis $H_{4}$ was not supported in the Indonesian model.

The direct effect is greater than indirect effect because the direct effect accounts for $67 \%$ of the total size in this multiple mediation model, while the indirect effect accounted for only 33\% (17.69\% for benevolence, $12.31 \%$ for ability, and 3\% for integrity). The total effect of Indonesia's multiple mediation model was 0.617 ; this implies that in Indonesia, satisfied customers can be loyal to internet banking without trusting it. So, the internet banking providers need to improve their e-services to meet their customers' needs and expectations.

In Taiwan, benevolence and integrity are significant mediators in the relationship between satisfaction and loyalty $(\beta=0.156 ; z=4.97 ; p=0.000)$ and $(\beta=0.103 ; z=$ 3.591; $p=0.000)$. These results supported hypotheses $H_{2}$ and $H_{4}$ in the Taiwanese model. It is consistent with research by Singh and Sirdeshmukh (2000), Flavián et al. 
(2006), and Ball et al. (2004). However, ability does not have a significant mediating effect on the relationship between customer satisfaction and customer loyalty $(\beta=$ $0.032 ; z=-0.804 ; p=0.421)$. In other words, hypothesis $\mathrm{H}_{3}$ is not supported in the Taiwanese model. It is consistent with the research by Madjid et al. (2013).

Based on these results, the indirect effect size is larger than the direct effect, because it takes $53.42 \%$ of the total size in this multi mediation model, and the total effect of Taiwan multi mediation model is 0.426 . The highest mediation effect is benevolence $(36.69 \%)$, followed by integrity $(24.19 \%)$. This means that in Taiwan, to gain customer loyalty, internet banking providers not only need to satisfy their customers, but also earn their trust.

Table 6 Group Comparison of Multiple Mediation Model

\begin{tabular}{|c|c|c|c|c|c|c|c|c|}
\hline & \multicolumn{3}{|c|}{ Indonesia } & \multicolumn{3}{|c|}{ Taiwan } & \multicolumn{2}{|c|}{ Comparison test } \\
\hline & $\beta$ & SE & $z$ & $\beta$ & SE & $z$ & Diff & $t$-value \\
\hline $\mathrm{CS} \rightarrow \mathrm{CL}$ & 0.414 & 0.038 & & 0.198 & 0.057 & & 0.215 & $3.184 * *$ \\
\hline $\mathrm{CS} \rightarrow \mathrm{T} 1$ & 0.450 & 0.046 & & 0.494 & 0.035 & & -0.045 & -0.768 \\
\hline $\mathrm{T} 1 \rightarrow \mathrm{CL}$ & 0.243 & 0.061 & & 0.316 & 0.060 & & -0.073 & -0.863 \\
\hline $\mathrm{CS} \rightarrow \mathrm{T} 2$ & 0.574 & 0.028 & & 0.611 & 0.037 & & -0.038 & -0.804 \\
\hline $\mathrm{T} 2 \rightarrow \mathrm{CL}$ & 0.132 & 0.050 & & -0.052 & 0.065 & & 0.184 & $2.274 *$ \\
\hline $\mathrm{CS} \rightarrow \mathrm{T} 3$ & 0.360 & 0.049 & & 0.484 & 0.033 & & -0.124 & -2.094 \\
\hline $\mathrm{T} 3 \rightarrow \mathrm{CL}$ & 0.052 & 0.046 & & 0.213 & 0.057 & & -0.161 & $-2.213 *$ \\
\hline $\begin{array}{l}\mathrm{CS} \rightarrow \mathrm{T} 1 \rightarrow \\
\mathrm{CL}\end{array}$ & 0.109 & 0.030 & $3.682 * * *$ & 0.156 & 0.031 & $4.972 * * *$ & -0.047 & -1.091 \\
\hline $\begin{array}{l}\mathrm{CS} \rightarrow \mathrm{T} 2 \rightarrow \\
\mathrm{CL}\end{array}$ & 0.076 & 0.029 & $2.637 * *$ & -0.032 & 0.040 & -0.804 & 0.108 & $2.222 * *$ \\
\hline $\begin{array}{l}\mathrm{CS} \rightarrow \mathrm{T} 3 \rightarrow \\
\mathrm{CL}\end{array}$ & 0.019 & 0.017 & 1.116 & 0.103 & 0.029 & $3.591 * * *$ & -0.084 & $-2.571 * *$ \\
\hline
\end{tabular}

Note: $* p<0.05, * * p<0.01, * * * p<0.001$

$\mathrm{CS}=$ Customer Satisfaction, $\mathrm{T} 1=$ Benevolence, $\mathrm{T} 2=$ Ability, $\mathrm{T} 3=$ Integrity, $\mathrm{CL}=$ Customer Loyalty

Based on the results in table 5, the multiple mediation models of two countries had a significant difference in the three paths of direct and indirect effect. First, the path of the direct effect of customer satisfaction (CS) on customer loyalty (CL), revealed the significant difference between the two models $(\beta$ Diff $=0.215 ; t=3.184 ; p$ $=0.002$ ). This difference shows that users of internet banking in Indonesia can be loyal if they are satisfied with their internet banking usage. In Taiwan, however, it is 
not as easy to gain loyal customers even if they are satisfied with the internet banking service, so internet banking providers need to ensure that their customers trust the internet banking site. However, this may be because technological advancement came earlier to Taiwan than to Indonesia. Taiwanese customers are therefore more accustomed to e-services, and harder to please.

Second, the path of ability (T2) as mediating between CS and CL, showed significant difference of model application in Indonesia and Taiwan $(\beta$ Diff $=0.018 ; t$ $=2.222 ; p=0.027)$. This occurred because T2 influences CL. There is a significant difference between the two models $(\beta$ Diff $=0.184 ; t=2.274 ; p=0.024)$. In Indonesia, ability had a positive significant mediating effect on CS and CL. This was not the case in Taiwan. So, in Taiwan, internet banking providers need to improve the competency and effectiveness of e-banking, the performance of internet banking, and the capability of their internet banking site. These improvements could establish customer loyalty after customers find that they are satisfied with their internet banking site.

Third, the path of integrity (T3) that mediates CS and CL, showed a significant difference between the models ( $\beta$ Diff $=-0.084 ; t=-2.571 ; p=-0.011)$. The path of integrity has effect to customer loyalty have significant difference between two models application $(\beta$ Diff $=-0.103 ; t=-2.094 ; p=-0.037)$. Integrity has positive significant effect as the mediator between CS and CL in Taiwan. In Indonesia, it does not. So, in Indonesia, to improve customer loyalty, the internet banking providers need to make good faith agreements, tell the truth, and keep their promises. This improvement will establish the customer loyalty after they are satisfied with their internet banking site.

\section{CONCLUSIONS AND LIMITATIONS}

\section{Conclusions}

To examine the research hypothesis, this research used Partial Least Square. The results of data analysis can be seen in table 7 .

The direct effect of customer satisfaction is not very strong, but it still has a positively significant influence on customer loyalty in Taiwan and Indonesia. It means that, in both countries, the higher the customer satisfaction, the more customer loyalty to internet banking will increase, and vice versa. This situation was found in both countries, because internet banking users had already experienced and evaluated the service and reported their satisfaction. They will compare their expectations with the performance of the internet banking site, and explain whether it matched, exceeded or fell short of their expectations. If they are highly satisfied, they are likely to keep using that internet banking site, or speak favorably of it to other people. These 
responses can show how loyal the users of internet banking are to their internet banking site.

Table 7 The Finding of Hypothesis Analysis

\begin{tabular}{cllc}
\hline & \multicolumn{2}{c}{ Hypothesis } & \multicolumn{2}{c}{ Finding } \\
\cline { 3 - 4 } & & Indonesia & Taiwan \\
\hline $\mathrm{H}_{1}$ & $\begin{array}{l}\text { Customer Satisfaction has a positive effect on } \\
\text { Trust }\end{array}$ & Supported & Supported \\
\hline & $\begin{array}{l}\text { Benevolence is a mediator of the relationship } \\
\text { between Customer Satisfaction and Customer } \\
\mathrm{H}_{2}\end{array}$ & Supported & Supported \\
\hline $\mathrm{H}_{3}$ & $\begin{array}{l}\text { Ability is a mediator of the relationship between } \\
\text { Customer Satisfaction and Customer Loyalty }\end{array}$ & Supported & Not Supported \\
\hline $\mathrm{H}_{4}$ & $\begin{array}{l}\text { Integrity is a mediator of the relationship between } \\
\text { Customer Satisfaction and Customer Loyalty }\end{array}$ & $\begin{array}{c}\text { Not } \\
\text { Supported }\end{array}$ & Supported \\
\hline
\end{tabular}

Benevolence had the highest mediating effect on the relationship between customer satisfaction and customer loyalty. In Indonesia and in Taiwan, benevolence had a significant effect as the mediator of customer satisfaction on customer loyalty. Users of internet banking in both countries prefer to be loyal to internet banks that care about their well-being, not just their own profit. To obtain customer loyalty, the internet banking providers cannot just focus on increasing customer satisfaction, but also on establishing and maintaining the benevolence of users of internet banking sites.

Ability was found to have a significantly mediating effect on customer satisfaction and customer loyalty in Indonesia. The internet banking providers need to increase customer satisfaction and bank ability in order to increase customer loyalty. In Taiwan, ability has no such mediating effect. In Indonesia, integrity does not mediate the effect of customer satisfaction on customer loyalty, but in Taiwan it does.

The main contributions of this research were to define and compare the dimensions of trust as the mediator in the relationship between customer satisfaction and customer satisfaction. This study then compared the integrated framework in Indonesia and Taiwan. Among the three dimensions of trust, the most important is benevolence, because it has a significant mediating effect in both countries. The other two dimensions, ability and integrity, were significant in only one of the two countries. Internet banking providers need to be genuinely interested in the welfare of internet banking users and seek their joint benefit. Providers of internet banking also need to 
act in their customers' best interest when new conditions arise for which a commitment was not made.

Internet banking providers should convince their customers that the internet banking site has their best interest at heart by offering the services that their customers need. Customers should believe that the internet banking site will do its best to help them whenever they need it, and not only during regular business hours.

\section{Limitations and Future Research}

One limitation of this research is that it had too few constructs or variables. Future research should have a more than three indicators in order to get a better description of constructs or variables. Future research should exam the antecedents of customer satisfaction as another variable, and evaluate its influence to trust and customer loyalty, and its outcomes for business performance. A second limitation is that the sample focused on internet banking users of the four biggest banks in Taiwan and Indonesia. These results cannot be generalized to the fields outside of banking. Finally, the research in e-commerce is be very dynamic, so future research can use time-series analysis.

\section{REFERENCES}

Akbar, M. M., \& Parvez, N. (2009). Impact of Service Quality, Trust, and Customer Satisfaction on Customers Loyalty. ABAC Journal, 29(1), 24-38.

Al-dweeri, R. M., Obeidat, Z. M., Al-dwiry, M. A., Alshurideh, M. T., \& Alhorani, A. M. (2017). The Impact of E-Service Quality and E-Loyalty on Online Shopping: Moderating Effect of E-Satisfaction and E-Trust. International Journal of Marketing Studies, 9(2), 92. https://doi.org/10.5539/ijms.v9n2p92

Bricci, L., Fragata, A., \& Antunes, J. (2016). The Effects of Trust, Commitment and Satisfaction on Customer Loyalty in the distribution sector. Journal of Economics, Business and Management, 4(2), 173-177. http://dx.doi.org/10.7763/JOEBM.2016.V4.386

Capgemini (2012) World retail banking report.

Chen, S. C., \& Dhillon, G. S. (2003). Interpreting Dimensions of Consumer Trust in E-Commerce. Information Technology and Management, 4(303-318). https://doi.org/10.1023/A:1022962631249

Chen, S. C. (2012). The customer satisfaction-loyalty relation in an interactive eservice setting: The mediators. Journal of Retailing and Consumer Services, 19(2), 202-210. https://doi.org/10.1016/j.jretconser.2012.01.001 
Chen, M. H., Tsai, K. M., Hsu, Y. C., \& Lee, K. Y. (2013). E-service quality impact on online customer's perceived value and loyalty. China-USA Business Review, 12(5).

Chu, P.-Y., Lee, G.-Y., \& Chao, Y. (2012). Service Quality, Customer Satisfaction, Customer Trust, and Loyalty in An E-Banking Context. Social Behaviour and Personality, 40(8), 1271-1284. https://doi.org/10.2224/sbp.2012.40.8.1271

Deng, Z., Lu, Y., Wei, K. K., \& Zhang, J. (2010). Understanding Customer Satisfaction and Loyalty: An Empirical Study of Mobile Instant Messages in China. International Journal of Information Management, 30(4), 289-300. https://doi.org/10.1016/j.ijinfomgt.2009.10.001

Dwyer, F. R., \& Tanner, J. F. (2002). Business Marketing: Connecting Strategy, Relationships, and Learning. New York: McGraw-Hill Companies,Inc.

Flavián, C., Guinalíu, M., \& Gurrea, R. (2006). The Role Played by Perceived Usability, Satisfaction and Consumer Trust on Website Loyalty. Information and Management, 43(1), 1-14. https://doi: 10.1016/j.im.2005.01.002

Grabner-Kräuter, S., \& Faullant, R. (2008). Consumer Acceptance of Internet Banking: The Influence of Internet Trust. International Journal of Bank Marketing, 26(7), 483-504. https://doi.org/10.1108/02652320810913855

Hair, J. F., Black, W. C., Babin, B. J., \& Anderson, R. E. (2010). Multivariate Data Analysis : A Global Perspective (Seventh ed.). New Jersey: Pearson Education, Inc.

Harris, L. C., \& Goode, M. M. H. (2004). The Four Levels of Loyalty and the pivotal role of Trust: A Study of Online Service Dynamics. Journal of Retailing, 80(2), 139-158. http://dx.doi.org/10.1016/j.jretai.2004.04.002

Henseler, J., Ringle, C. M., \& Sinkovics, R. R. (2009). The use of partial least squares path modeling in international marketing. In New challenges to international marketing (pp. 277-319). Emerald Group Publishing Limited.

Hollensen, S. (2010). Marketing Management: a Relationship Approach Harlow: Pearson Education Limited.

Horppu, M., Kuivalainen, O., Tarkiainen, A., \& Ellonen, H. K. (2008). Online satisfaction, trust and loyalty, and the impact of the offline parent brand. Journal of Product \& Brand Management, 17(6), 403-413. https://doi.org/10.1108/10610420810904149

Kassim, N., \& Abdullah, N. A. (2010). The Effect of Perceived Service Quality Dimensions on Customer Satisfaction, Trust, and Loyalty in E-Commerce Settings: A Cross Cultural Analysis. Asia Pacific Journal of Marketing and Logistics, 22(3), 351-371. http://dx.doi.org/10.1108/13555851011062269 
Kim, C., Zhao, W., \& Yang, K. H. (2008). An Empirical Study on the Integrated Framework of e-CRM in Online Shopping: Evaluating the Relationship Among Perceived Value, Satisfaction, and Trust Based on Customers' Perspective. Journal of Electronic Commerce in Organizations, 6(3), 1-19. http://dx.doi.org/10.4018/jeco.2008070101

Kasiri, L. A., Guan Cheng, K. T., Sambasivan, M., \& Sidin, S. M. (2017). Integration of standardization and customization: Impact on service quality, customer satisfaction, and loyalty. Journal of Retailing and Consumer Services, 35, 91-97. http://dx.doi.org/10.1016/j.jretconser.2016.11.007

Kline, R. B. (Ed.). (2005). Principles and Practice of Structural Equation Modeling. New York: The Guilford Press.

Kocoglu, D. (2012). Customer Relationship Management and Customer Loyalty; A Survey in The Sector of Banking. International Journal of Business and Social Science, 3(3), 282-291.

Komiak, S. X., \& Benbasat, I. (2004). Understanding customer trust in agent-mediated electronic commerce, web-mediated electronic commerce, and traditional commerce. Information Technology and Management, 5(1-2), 181-207. http://dx.doi.org/10.1023/B:ITEM.0000008081.55563.d4

Konana, P., Menon, N. M., \& Balasubramanian, S. (2000). The implications of online investing. Communications of the ACM,43(1), 34-41. http://dx.doi.org/10.1145/323830.323842

Kotler, P., \& Keller, K. L. (2012). Marketing Management (14e Global Edition ed.). New Jersey: Prentice Hall International, Inc.

Kuo, Y. F., Wu, C. M., \& Deng, W. J. (2009). The Relationships Among Service Quality, Perceived Value, Customer Satisfaction, and Post-Purchase Intention in Mobile Value-Added Services. Computers in Human Behavior, 25(4), 887-896. http://dx.doi.org/10.1016/j.chb.2009.03.003

Ladhari, R., \& Leclerc, A. (2013). Building Loyalty with Online Financial Services Customers: Is There a Gender Difference? Journal of Retailing and Consumer Services, 20(6), 560-569. http://dx.doi.org/10.1016/j.jretconser.2013.07.005

Liao, N. N. H., \& Wu, T.-c. (2009). The Pivotal Role of Trust in Customer Loyalty: Empirical Research on the System Integration Market in Taiwan. The Business Review, Cambridge, 12(2), 277-283.

Madjid, R., Hadiwidjojo, D., Surachman, \& Djumahir. (2013). The Role of Customer Trust and Commitment as Mediator for the Relation between Customer Satisfaction and Loyalty at Bank Rakyat Indonesia (BRI) Kendari Southeast 
Sulawesi. International Journal of Business and Management Invention, 2(4), 53-64.

McKnight, D. H., Choudhury, V., \& Kacmar, C. (2002). Developing and validating trust measures for e-commerce: An integrative typology. Information Systems Research, 13(3), 334-359. http://dx.doi.org/10.1287/isre.13.3.334.81

Preacher, K. J., \& Hayes, A. F. (2008). Asymptotic and resampling strategies for assessing and comparing indirect effects in multiple mediator models. Behavior research methods, 40(3), 879-891. http://dx.doi.org/10.3758/BRM.40.3.879

Picón, A., Castro, I., \& Roldán, J. L. (2014). The relationship between satisfaction and loyalty: A mediator analysis. Journal of Business Research, 67(5), 746-751. https://doi.org/10.1016/j.jbusres.2013.11.038

Prougestaporn, P., Visansakon, T., \& Saowapakpongchai, K. (2015). Key success factors and evaluation criterias of e-learning websites for higher education. International Journal of Information and Education Technology, 5(3), 233. http://dx.doi.org/10.7763/IJIET.2015.V5.507

Roostika, R. (2011). The effect of perceived service quality and trust on loyalty: Customer's perspectives on mobile internet adoption. International Journal of Innovation, Management and Technology, 2(4), 286.

Sheng, T., \& Liu, C. (2010). An empirical study on the effect of e-service quality on online customer satisfaction and loyalty. Nankai Business Review International, 1(3), 273-283. http://dx.doi.org/10.1108/20408741011069205

Setó-Pamies, D. (2012). Customer loyalty to service providers: examining the role of service quality, customer satisfaction and trust. Total Quality Management \& Business Excellence, 23(11-12),

1257-1271. http://dx.doi.org/10.1080/14783363.2012.669551

Singh, J., \& Sirdeshmukh, D. (2000). Agency and Trust Mechanisms in Consumer Satisfaction and Loyalty Judgments. Journal of the Academy of Marketing Science, 28(1), 150167.

Slenders, W. J. (2011). The 3 Elements of Trust. Accessed on January 17, 2013 from http://www.transcendmgt.com/assets/files/The $\% 203 \% 20$ elements $\% 20$ of\%20trust\%20-\%20December\%202011a.pdf.

Sobihah, M., Mohamad, M., Ali, N. A. M., \& Ismail, W. Z. W. (2015). E-commerce service quality on customer satisfaction, belief and loyalty: a proposal. Mediterranean Journal of Social Sciences, 6(2), 260. http://dx.doi.org/10.5901/mjss.2015.v6n2p260

Urban, G. L., Sultan, F., \& Qualls, W. J. (2000). Placing trust at the center of your Internet strategy. MIT Sloan Management Review, 42(1), 39. 
Usman, H. (2015). Customers Trust on Islamic Banks in Indonesia. Journal of Asian Finance, Economics, and Business, 2(1), 5-13. http://dx.doi.org/10.13106/jafeb.2015.vol2.no1.5.

van Esterik-Plasmeijer, P. W., van Esterik-Plasmeijer, P. W., van Raaij, W. F., \& van Raaij, W. F. (2017). Banking system trust, bank trust, and bank loyalty. International Journal of Bank Marketing, 35(1), 97-111. http://dx.doi.org/10.1108/IJBM-12-2015-0195

Wong, D. H., Loh, C., Yap, K. B., \& Bak, R. (2009). To Trust or Not to Trust The Consumer's Dilemma with E-banking. Journal of Internet Business, (6), 1-27.

Yang, H. E., Wu, C. C., \& Wang, K. C. (2009). An Empirical Analysis of Online Game Service Satisfaction and Loyalty. Expert Systems with Applications, 36(2), 1816-1825. http://dx.doi.org/10.1016/j.eswa.2007.12.005

Yoon, S. J. (2002). The antecedents and consequences of trust in online-purchase decisions. Journal of interactive marketing, 16(2), 47-63. https://doi.org/10.1002/dir.10008 